\title{
THE MAIN CHARACTERISTICS OF STEPHEN KING'S IDIOSTYLE
}

\author{
Svetlana S. Takhtarova \\ Kazan Federal University, Kazan, Russia \\ Amelia Sh. Zubinova \\ Kazan Federal University, Kazan, Russia
}

\begin{abstract}
The paper presents stylistic value of simile and metaphor as the major features of Stephen King's idiostyle. The linguistic analysis of some novels (1408, Carrie, The Shining, Dreamcatcher, Dead Zone) is aimed at discovering sematic and structural types of simile and metaphor, revealing their functions in the content development. Structural analysis of simile and metaphor constituency in the above mentioned novels resulted in allocating some formal patterns: a one-term verbal simile (as if ... verb, verb ... like ... verb), a two-term attribute simile (noun-like), a two-term or three-term nominative simile, and simple (a one-image) or expanded pattern of metaphor. The sematic analysis of Stephen King's novels lets reveal the compound character of simile and metaphor use. Both tropes are used predominantly to create tension in narration that is often raised up to the atmosphere of horror, the latest is considered by the researchers to be a major feature of the idiostyle of the author under study. Having described some semantic ways of expanding horror, death, savageness, mood and expressiveness with similes and metaphors, the researchers concluded that these tropes perform leading functions in personalizing Stephen King's idiostyle: constructing images and describing feelings that characters are going into along with creating the tone of tension and horror; performing common stylistic function despite the fact that they differ in the way the atmosphere of tension and horror is built: explicit realization in simile and implicit by various types of morphemes in metaphor.

Key words: English language, simile, metaphor, semantic types of metaphor, structural types of metaphor, semantic types of simile, structural types of simile, Stephen King.

Citation. Takhtarova S.S., Zubinova A.Sh. The Main Characteristics of Stephen King's Idiostyle. Vestnik Volgogradskogo gosudarstvennogo universiteta. Seriya 2, Yazykoznanie [Science Journal of Volgograd State University. Linguistics], 2018, vol. 17, no. 3, pp. 139-147. DOI: https://doi.org/10.15688/jvolsu2.2018.3.14
\end{abstract}

УДК 81 '373.612.2

Дата поступления статьи: 15.05.2018

ББК 81.053 .1 Дата принятия статьи: 11.06.2018

\section{СРАВНЕНИЕ И МЕТАФОРА В ИДИОСТИЛЕ С. КИНГА}

\section{Светлана Салаватовна Тахтарова}

Казанский федеральный университет, г. Казань, Россия

Амелия Шамилевна Зубинова

Казанский федеральный университет, г. Казань, Россия

Аннотация. В статье выявлены существенные характеристики идиостиля С. Кинга, отражающие специфику авторского использования сравнений и метафор. На материале романов «1408», «Кэрри», «Сияние», «Ловец снов», «Мертвая Зона» описаны семантические и структурные типы сравнений и метафор, показаны их функции в формировании содержания художественного текста. Структурный анализ позволил установить несколько типов формальных моделей построения сравнения и метафоры: однозвенное глагольное сравнение (as if ... verb, verb ... like ... verb), двухзвенная атрибутивная структура (noun-like), двух- и трехзвенная номина- 
тивную модель сравнения, а также простые (однообразные) и сложные (многообразные) модели метафоры. В результате семантического анализа романов С. Кинга выявлен сложный характер участия образного сравнения и метафоры в выражении жанровой специфики. Оба тропа активно используются для создания напряжения повествования и повышения атмосферы ужаса. Они выполняют сходные функции в текстах, однако отличаются способами создания атмосферы напряжения и ужаса: если в сравнении образы представлены прямо, то для метафоры характерны косвенные и непрямые модели передачи смысла. Описав образые сравнения и метафоры как средства порождения ужаса, ощущения смерти, страха и иных эмоций, авторы статьи пришли к выводу о том, что данные тропы персонализируют стиль С. Кинга.

Ключевые слова: английский язык, сравнение, метафора, семантические типы метафоры, структурные типы метафоры, семантические типы сравнения, структурные типы сравнения, Стивен Кинг.

Цитирование. Тахтарова С. С., Зубинова А. Ш. Сравнение и метафора в идиостиле С. Кинга // Вестник Волгоградского государственного университета. Серия 2, Языкознание. - 2018. - Т. 17, № 3. - С. 139-147. DOI: https://doi.org/10.15688/jvolsu2.2018.3.14

\section{Introduction}

According to Russian linguists, simile is a trope in the structure of which two incompatible concepts, usually related to different classes of phenomena, fall into comparison among themselves by one of the parameters, and the comparison gets a formal expression in the words such as: as, such as, as if , like, seem, etc. [Galperin, 2012]. Foreign researchers also define simile as indication of similarity in two concepts. Thus, in the work of S. Shamisa, simile is defined as the affirmation of the similarity of two objects in one or more qualities, i.e. simile is a figure of speech requiring an explicit connection between the object, the subject and the construction that connects them [Shamisa, 2004]. Simile is a figure of speech that consists in comparison of two different objects with the aim to reveal their similarity [Hussein, Sawalha, 2016]. Simile is seen as the likeness of the depicted objects, phenomena, facts, images that are well recognized by the audience. It is established that such comparison presents the implied thought in a more visual and affective way [Efimov, 1957]. Moreover, the value of simile in the text is undeniable due to two reasons: 1) exaggeration of the weak parameter of the subject of simile with the stronger parameter, 2) correlation by the parameter established by the basis of comparison [Ogoltsev, 2010]. As for the types of similes, there are different approaches to this question: some linguists reveal comparisons and similes. Similes compare objects from different fields; comparisons do it according to logic and with the purpose of establishing the degree of their sameness or difference [Gargani, 2016].
Metaphor is a hidden comparison, it is carried out by referring the name of one object to another, which reveals the main feature of the second, the trope is formed with the association on similarity [Arnold, 2012, p. 58]. Metaphor is one of the most common tropes in world literature. It is based on similarity of objects or phenomena in a variety of ways. It is thought to arise from simile, as the comparison of a new object with the already known one and accompanied by the isolation of their common features. The peculiarity of metaphor is revealed in its semantic structure: the members of the trope are merged so toughly that the first element (which was compared) is superseded and completely replaced by the second (with which it was compared). Metaphor, like all tropes, is based on the meanings the word possesses, it is a relation between the dictionary and contextual logical meanings, being based not only on the essential and general qualities of objects (phenomena) but also on the wide range of its secondary properties or features, metaphor affiliates certain properties of the two corresponding concepts. For authors these "secondary" signs, expressing moments of sensual presentation, are means of revealing through them the essential features of the reflected reality. Metaphor enriches our understanding of this subject, focuses attention on new characteristics of the phenomena, and in fiction it acquires special significance.

\section{Material and methods}

The data collection process was based on S. King's novels (1408, Carrie, The Shining, Dreamcatcher, Dead Zone), 500 similes and 200 metaphors were selected and then studied 
with the aim to find the most frequent semantic and structural types of similes and metaphors. Their functions and relations with the idiostyle of the author were analyzed. The following methods were used: analysis, statistical method, and sampling method. Sampling method was used during selection of similes and metaphors; then corpus was analyzed and divided into semantic and structural types. Finally, the conclusion on the number of tropes was made with the use of statistical method.

\section{Results}

Simile is one of the most frequent tropes used by S. King in his novels. It introduces symbolism into idiostyle, creates tension, makes the text more vivid and acute, it also represents fiction world, people, their emotions, etc. It is highly important to analyze similes in the frame of S. King's books because they help to reveal genre of his texts due to lexemes used and images created. S. King's works are often characterized by compound nature, as the author mixes different genres in his texts: horror, science fiction, mystery, and some others. But in most cases the main aim is to scare readers and to make them feel the same emotions as the characters of his books. This goal is achieved through the choice of lexemes and verbal images, which makes literary analysis crucial. Below there goes explanation on semantic distinction of the tropes under study.

Semantic distinction of similes is based on revealing common lexical components. Similes are mostly used to express the atmosphere of horror, describe people and their emotions, present objects or concepts of the world that is depicted by the author. Each type carries out different function.

The first type is characterized by lexemes that create an atmosphere of horror in the text, for example, such words as sinning soul, blood, rot, death, polarizing shield, etc. However, there may be cases when the atmosphere of tension is structured implicitly in the text. The first example shows how a horrifying image is built, it is used in order to describe a mediocre object, simile makes it more frightening due to its lexical structure and image:

(1) the finger-holes in the dial looked like surprised white eyes (King-3, p. 392).
Here the atmosphere of horror is created with the adjective white, because along with the collocation surprised eyes it makes the scene unnatural. This simile produces a visual image of something unusual and odd. The use of adjective white as the attribute of eye evokes associations with dead body, or the eyes of a monster. This association becomes leading in perception of the paragraph; it probably can evoke certain emotions in readers.

The second type of simile has similar function and image, it also presents a simple object through a rather odd image:

(2) the pictures began to bend, turning into shapes like the windshields of old cars (King-3, p. 396).

The atmosphere of tension is created due to the use of the verb to bend, which in this case carries additional information like to be distorted. The image points to something supernatural, which is seen in the hotel room number 1408. Of course it is a part of narration, but the trope is based on comparison of two rather diverse objects 'the picture' and 'windshields of old cars', such logical incoordination makes the situation tense for the readers.

The next sample helps describe environment, which becomes distorted with scary symbols:

(3) And to his left, where the picture of the fruit had been, the wall was bulging outward toward him, splitting open in those long cracks that gaped like mouths, opening on a world from which something was now approaching (King-3, p. 34).

Due to the presence of the indefinite pronoun something in this context it together with the simile those long cracks that gaped like mouths brings a shade of frightening uncertainty. It is interesting, that the author uses such indefinite pronouns quite often in the books under study; we assume that it is done because of associations, which this part of speech bears. Probably, pronoun something evokes associations to some monster, hidden in the dark, some uncertain force which would harm the book's characters.

Similes with the lexical component that can create the atmosphere of horror or tension reflect the major feature of the genre. The author's special skill is manifested in simulating similes that carry a side effect of horror, without using explicit frightening lexemes. S. King uses odd associations 
in order to create images, which can evoke complex emotions in readers' minds.

The second type is represented with the similes with the color lexeme. Color lexeme brings expressiveness and, in some cases, inject the atmosphere, red and black lexemes are used due to associations to darkness, blood, death, and danger:

(4) it was as red as a stoplight (King-2, p. 27).

Similes of this type usually describe objects of real world or carry function of estimation. They bring color, brightness to fiction images, make them more real and dynamic. The role of color in some S. King's novels is important, this attribute helps distinguish people, objects or situation.

Similes with the lexical component 'representatives of the fauna' are usually used to describe the characters, their behavior, and appearance. Such similes reveal savageness in human nature; it is a reminder of dark and wild part of humankind.

In the example below the scene of hunting is introduced, the character enters an animal state and with the help of a lexeme alligator the author expresses an aggressive attitude to another person:

(5) To his horror, he realized he was still tracking the man below with the Garand, as if some stubborn alligator deep in his brain refused to let go of the idea that the man in the brown coat was prey (King-2, p. 30).

Alligator is a dangerous and strong animal, and when a person is compared to it some characteristics are implied. It is important to point to a partly unconscious state of the personage, which is vivid due to use of such lexemes as realized, refused. So, simile does not only compares the person to the animal but also reveals the dark part of human nature, its savage side.

In some cases, fauna-lexemes characterize the objects of the fiction world, as it is in the case when movements of cords are compared to movements of snakes:

(6) All the heavy light cables were in the air, flowing and jerking and writhing like snakes out of an Indian fakir's basket (King-1, p. 52).
The image is also complemented with collocation an Indian fakir's basket, which immediately brings a set of different associations; of course, it transforms and broadens the image of simile, due to emotions evoked in reader's mind.

In the last example, the sounds of laughter are identified with the sounds of black birds flapping the wings.

(7) She went down them in great, awkward leaps, with the sound of the laughter flapping around her like black birds (King-1, p. 56).

In connection with the use of such a trope, laughter is perceived as something annoying, frightening and intrusive. This image emphasizes the relationship between girls and Carry, their dislike to her is tangible and strong. Also her perception of this situation is great, it touches her, and it is seen in the use of attribute black.

Similes with lexical components of color and fauna representatives perform the function of describing objects, characters or events. They bring expressiveness and brightness to the introduced images; they help to create nontraditional verbal identification of objects, as well as the emotional state of heroes and their perception of the situation.

Similes with the lexical component 'object' are most often used to describe the surrounding world. In the structure of such similes, abstract nouns are sometimes used along with the main lexeme.

The following example is interesting because of its confronting character to the main situation. In the previous paragraph, one of the heroines, Susan, understands that she is not a good girl anymore, she has made horrible mistakes. Then the author gives us the following simile:

(8) The late afternoon sunlight, warm as oil and sweet as childhood, slanted through the high, bright gymnasium windows (King-1, p. 32).

The warmth of sunlight is likened to oil and childhood. So, here we can see underlining of the fact that the heroine, who mocks her schoolmate, is a child. Such antithesis is made due to the bright image of simile, which brings together abstract notion and object of material life.

Another simile is a part of the paragraph about the death of a schoolmate of Susan, here 
she knows that Carrie did it. Her confidence shapes into this simile:

(9) She had no idea how she knew it, but the conviction was as pure and right as arithmetic (King-1, p. 67).

The referent of simile is expressed by an abstract noun, and the agent - by the notion of the surrounding world.

In the next example, the simile agent is the subordinate clause; because of the extended structure simile expresses not only the characteristics of the object, but also its action:

(10) She envisioned the door swinging shut, and the door did just that, as if moved by a light breeze (King-1, p. 36).

According to semantic typology and statistical analysis we can assume that the most considerable semantic type of similes is similes expressing the atmosphere of horror. This type represents the dominant genre of S. King's novels - horror; they also describe characters and surrounding them world; transfer estimation of heroes. Due to the choice of the lexemes used, such similes help to create the atmosphere of horror and tension, as well as reveal characteristics of personages and their environment.

In the works of S. King different structural types of similes may be distinguished. In this study we use the classification of structural types proposed by I. Kocheshkova (three-term nominative, twoterm nominative, two-term adjective, one-term verbal) [Kocheshkova, 2004, p. 10].

Three-term nominative simile has the following structure - the referent and the noun agent; the referent (what compared), the agent (with what compared) and the base are explicated (attribute).

In the example below the author uses simile in order to make a description of the character. The image reveals that the character is very scared, the use of lexeme pale usually introduces the emotion of fear:

(11) Olin's manicured hands were clasped behind him now, and Mike saw that the little man's face was as pale as cream (King-3, p. 383).

This simile is also referred to the type of trite similes, nevertheless the image is bright and the reader easily understands the emotion.
This type is introduced mostly by author's similes. Author's similes are expressive and metaphorical. Thus, in the example (13), the mother's hand is identified with a steel handcuff. Through the simile the reader understands the nature of relationship between the mother and daughter. This detail is significant for S. King's works because he usually pays attention to the problem of violence in the family and coarse education. Due to it, the use of the trope here emphasizes the problem:

(12) She tried to struggle to her feet and Momma's hand, as strong and pitiless as an iron manacle, forced her back to her knees (King-1, p. 16).

In the next case of simile (14), the referent and the agent are nominated by word combinations; one of the referent members is represented by an abstract noun fear. The base of simile is represented by two adverbs quickly and soundlessly. Such a simile simulates integral image, compares the subject, based on its two characteristics:

(13) Momma's eyes, gone as quickly and soundlessly as summer lightning (King-1, p. 17).

Three-term nominative similes introduce bright, vivid image, because of their structure the attribute is explicit, it brings additional information. In the author's similes abstract and specific nouns are combined, which make the image more complex and profound.

Two-term nominative similes consist of an explicated referent and an agent, as it is in the example below, where the tongue is compared with $a$ dry sheet:

(14) My tongue is felt like a little dried-up plant (King-1, p. 9).

With the help of this trope, the author describes implicitly the state of the character, the reader perceives the situation properly: the character cannot say a word due to the situation described.

In the next example the simile is used to describe the appearance of the character, eyes are compared with poached eggs:

(15) Her eyes were very large in the rimless glasses; they looked like poached eggs (King-1, p. 16). 
The trope is not performing an aesthetic function; however the image is expressive and vivid.

In the last example, the abstract noun dislike is identified with a paper snake:

(16) Sue nodded and raised a hand, although dislike rose in her throat like a paper snake (King-1, p. 21).

The concepts that have different characteristics are united in a single image due to the use of the verb to rise, which is a common feature for both concepts.

Two-term nominative similes are the most numerous type of simile in S. King's books. They do not have a base in their structure, but sometimes there is an attribute connected with the agent, which brings additional information and details into the image.

The agent of a two-term adjective simile is expressed by an adjective formed by means of suffixation or compositional constituency, the referent and the agent are explicated. This type of similes is similar to attribute, because reveals characteristics of object:

(17) The Wheel began to slow and now they could hear the metronome-like tick-tock of the small wooden clapper sliding past the pins that divided the numbers (King-4, p. 27);

(18) Next morning she comes down and tries to put on this big act, but all day she's gettin paler an paler, and Mr. Ullman asks her, sorta-like, smack-like, sorta diplomatic-like, would she like him to notify the state cops, just in case maybe he had a little accident or something (King-5, p. 17).

A one-term verbal simile consists of an explicated agent expressed by a verb. Sometimes it is difficult to distinguish between the agent and the image created by a sentence:

(19) For a moment Sue felt as if she were watching a candle flame disappear down a long, black tunnel at a tremendous speed (King-1, p. 71).

This example introduces a rather scary image. Emotional state of heroine is vague, because she somehow feels that Carry is dying. Candle is a symbol of Carry's soul that is going away, together with all problems and awful events.

The next sample of simile describes the emotions of the character, she cannot make a step, say something, she feels awkward and scared:
(20) They were all just staring. I felt like I was frozen in ice (King-1, p. 51).

This simile is trite, but the image nevertheless is bright, due to the fact that it brings different emotions, helps understand the whole situation from emotional side.

Sometimes one can find another construction:

(21) Jonesy saw a pair of good-sized wildcats moving between two little groups of deer and actually rubbed his eyes, as if to clear them of a mirage (King-2, p. 64).

Here the whole sentence creates image, it is difficult to divide the simile and the context of it. We assume that every sentence constituent is important for structuring simile. This trope describes the situation when one does not know where the reality is, if he can see the real world or something else.

Such similes, in view of the peculiarity of their structure, compare the actions of objects or characters; the use of verbs gives dynamism to the surrounding world. The author displays images in which the object or character ceases to be motionless.

Metaphor is the second most frequent trope in the S. King's novels after similes. Instable use of metaphors in the works of the writer should be considered. The nature of metaphors and, in general, the metaphorization of images is dictated, above all, by S. King's setting to create an atmosphere of tension and hidden horror, a description of the inner experience of characters in similar situations and their appearance. The main difference between simile and metaphor is in the way of comparison; simile has explicit description, whereas metaphor - implicit.

Semantic distinction is made on the basis of revealing common lexical components in metaphors. Metaphors mostly express the atmosphere of horror and objects or concepts of the surrounding world.

There are metaphors, which include lexemes (i.e. blood, death, etc.) aimed at creating an atmosphere of horror or tension.

The example (22) describes a part of human mind, wild and unpredictable. The phrase savage things brings a frightening connotation to the metaphor: 
(22) the subconscious level where savage things grow (King-2, p. 396).

The use of word thing reveals uncertainty, because through it imagination of reader begins to form different images of upcoming terror. This image provides the thought that sometimes human consciousness may lead to impulsive behavior, due to which the character becomes unpredictable, the reader does not know what to expect from them.

In the next example the atmosphere of horror is created by the phrase screaming in miserable voices.

(23) Dreams age faster than dreamers, that is a fact of life Pete has discovered as the years pass. Yet the last ones often die surprisingly hard, screaming in low, miserable voices at the back of the brain (King-2, p. 10).

The image is vividly presented. The idea of dying dreams is incredible; probably the reader would remember this phrase due to the acute image. This metaphor has slight tint of personification, because an abstract notion like dream is said to behave like a human: it ages, screams, dies. Such complex image significantly conveys the idea and becomes the reflection of dominant genre, because there is nothing more horrible than dying dreams.

In the example (24), the metaphor is used to describe the deer the protagonist hunts for. The use of two close concepts - dark and black - is interesting. These epithets enhance the qualitative characteristics of the eyes. In his description the author emphasizes this feature as something potentially important:

(24) one eye so dark it was almost the black of jeweler's velvet (King-2, p. 29).

The next widely used concept in metaphors and similes is the concept of darkness:

(25) a darkness has come into his own life that polarizing filter - and Henry finds he has no objection to this (King-2, p. 16);

(26) as the neurosis deepens, so does the interior darkness (King-2, p. 16).

The concept darkness helps to construct an image, it also should be considered as a figure of rhythm. It may be seen in the novel Dreamcatcher: there are 33 sentences with the word darkness in 385 pages. We assume that this number is quite big and the word darkness reveals not only its first definition, but carries out another function - create the tone of tension in narration.

Metaphors, which include a lexeme expressing objects or concepts of the surrounding world, bring expressiveness to the description of characters or objects of reality.

In the example (27), the implicit comparison of the eyes and lenses seems appropriate because it describes character's behavior like a doll that is unencumbered by the intellectual activity. The author strengthens this characteristic of the personage through the introduction of this metaphor:

(27) wide eyes not blinking as the snowflakes whirled into them to melt on their warm living lenses (King-2, p. 54).

In the example below, the metaphor reflects the change in the mood of the main character:

(28) Carrie went into the house and closed the door behind her. Bright daylight disappeared and was replaced by brown shadows, coolness, and the oppressive smell of talcum powder. The only sound was the ticking of the Black Forest cuckoo clock in the living room. Momma had gotten the cuckoo clock with Green Stamps (King-1, p. 11).

Using the lexemes brown, coolness and the phrase oppressive smell, the author makes his reader clearly aware of the depression and inner anguish of the character.

The next example of metaphor shows a capacious character description. Barry Newman is distinguished by an unhealthy complexion, which was impressively reflected in the description of his characteristic and implicit comparison with $a$ herd of bulls:

(29) At first Henry sits where he is, not moving, listening to the departing thunder of the one-man buffalo herd that is Barry Newman (King-2, p. 19).

In example (30), the blush is compared with red roses. Along with the epithet deadly pale, this comparison reinforces the description of the morbid character of the hero, despite the seeming romanticism of the metaphor: 
(30) 'Stop it!' Barry is sitting up now, he hasn't needed Henry to give him a hand this time, and he is deadly pale except for little red roses, one growing in each check (King-2, p. 18).

The structural delineation of metaphors was based on the isolation of simple and complex metaphors. As it is shown by the analysis of factual material, the idiostyle of S. King is characterized by simple metaphors consisting of one image. Despite the presence of detailed metaphors, the frequency of simple metaphor usage is higher.

Among simple metaphors there are ones that are close in structure to the epithets, they perform a descriptive function:

(31) Barry is an eating machine (King-2, p. 16);

(32) he is a lipid goldmine (King-2, p. 17).

The expanded metaphors impart expressiveness to the described state or image, by using such metaphors, the author emphasizes the complexity of the event or situation for perception:

(33) body filled with sunlight, musical notes in her mind, butterflies behind her skull in the cage of her mind (King-1, p. 14);

(34) death had had him in the street, and had then to come to the hospital to finish the job, death masquerading as a man (or perhaps it had been a woman, it was hard to tell) meant Jonesy (King-2, p. 28).

\section{Conclusion}

Thus, the semantic distinction of similes and metaphors under study revealed some semantic value of these tropes and their functions in setting genre features of the idiostyle of Stephen King. The features and functioning of similes and metaphors in S. King's works seem to be consistent with the group affiliation of the tropes. The semantic richness of similes and metaphors helps to express an atmosphere of horror, that is a major reflection of the genre; being semantically and conceptionally joined, these types participate in creating atmosphere of tension and horror. This is evidently presented in the data - about $40 \%$ of trope usage. Due to the vividness of images, similes and metaphors evoke different associations, and their decoding depends on every reader's imagination potential. The other types of similes and metaphors more often perform a descriptive and emotional-evaluative function, add expressiveness, brightness and imagery to the fragments.

Structural differentiation of similes and metaphors allowed us to analyze the frequency of their usage in the author's works. The most frequent type is a group of two-term nominative similes (about $60 \%$ ), the other groups have approximately the same number of examples. This type does not have a base in its structure; due to this it lacks the additional attribute and detail of the image. Among the metaphors, the most widely used type is a simple metaphor with one image (approximately $55 \%$ ).

\section{REFERENCES}

Arnold I.V., 2012. Stylistics of the modern English language. Moscow, Prosveshchenie Publ. 384 p.

Efimov A.I., 1957. Stylistics of artistic speech. Moscow, Izd-vo Mosk. un-ta. $448 \mathrm{p}$.

Galperin I.R., 2012. Essays on stylistics of the English language. Moscow, Librocom Publ. $376 \mathrm{p}$.

Gargani A., 2016. Similes as poetic comparisons. LINGUA, vol. 175, pp. 54-68.

Hussein R., Sawalha M., 2016. A Corpus-based study of similes in British and American. Arab World English Journal (AWEJ), vol. 7, no. 2, pp. 49-60.

Kocheshkova I.Y., 2004. Similes as a reflection of the author's worldview in the works of J. Fowles. Cand. philol. sci. abs. diss. Barnaul. 22 p.

Ogoltsev V.M., 2010. Stable comparisons in the system of Russian phraseology. Moscow, Librocom Publ. $178 \mathrm{p}$.

Shamisa S., 2004. Rhetoric 2. Tehran, Payamnoor Publication. 55 p.

\section{SOURCES}

King S., 2000. Carrie. New York, Simon and Schuster. $208 \mathrm{p}$.

King S., 2001. Dreamcatcher. London, Hodder and Stoughton. $385 \mathrm{p}$.

King S., 2007. Everything's Eventual. Hachette UK, London. pp. 365-403.

King S., 2016. The Dead Zone. New York, Simon and Schuster. $592 \mathrm{p}$.

King S., 2006. The Shining. London, Hodder and Stoughton. $497 \mathrm{p}$. 


\section{Information about the Authors}

Svetlana S. Takhtarova, Doctor of Sciences (Philology), Associate Professor, Head of the Department of Translation Theory and Practice, Kazan Federal University, Kremlevskaya St., 18, 420008 Kazan, Russia, alfia@mail.ru, https://orcid.org/0000-0002-9268-6892

Amelia Sh. Zubinova, Postgraduate Student, Department of Translation Theory and Practice, Kazan Federal University, Kremlevskaya St., 18, 420008 Kazan, Russia, Vivid_bibi@mail.ru, https:// orcid.org/0000-0002-4838-3966

\section{Информация об авторах}

Светлана Салаватовна Тахтарова, доктор филологических наук, доцент, заведующая кафедрой теории и практики перевода, Казанский федеральный университет, ул. Кремлевская, 18, 420008 г. Казань, Россия, alfia@mail.ru, https://orcid.org/0000-0002-9268-6892

Амелия Шамилевна Зубинова, аспирант кафедры теории и практики перевода, Казанский федеральный университет, ул. Кремлевская, 18, 420008 г. Казань, Россия, Vivid_bibi@mail.ru, https://orcid.org/0000-0002-4838-3966 